\title{
Zasady i metody normalizacji testów przetwarzania słuchowego
}

\section{Essentials and methods of the normalization of speech perception tests}

\author{
Monika Lewandowska, Agnieszka Pluta \\ Instytut Fizjologii i Patologii Słuchu, Światowe Centrum Słuchu, Naukowe Centrum Obrazowania \\ Biomedycznego, Warszawa/Kajetany
}

\begin{abstract}
Adres autora: Monika Lewandowska, Światowe Centrum Słuchu, Naukowe Centrum Obrazowania Biomedycznego, ul. Mokra 17, Kajetany, 05-830 Nadarzyn, e-mail: m.lewandowska@ifps.org.pl
\end{abstract}

\section{Streszczenie}

\begin{abstract}
W ostatnich latach na świecie obserwuje się zwiększenie liczby dzieci z deficytami w zakresie ośrodkowych procesów przetwarzania słuchowego (ang. central auditory processing, CAP). Mimo dużej skali zjawiska, w Polsce, jak dotąd, nie opracowano wystandaryzowanych narzędzi psychometrycznych służących do diagnozy CAP. Nie istnieją także ogolnopolskie normy dla tych testów. Celem niniejszej pracy było zaprezentowanie planu polskiej standaryzacji oraz normalizacji testów. W pierwszej części przypomniano ogólne zasady tworzenia narzędzi psychometrycznych. Następnie opisano popularne w innych krajach baterie testów do oceny ośrodkowych procesów przetwarzania słuchowego (SCAN, MAPA), które posiadają dobre właściwości psychometryczne oraz opracowane normy. Na podstawie ww. testów sformułowano zalecenia dotyczące polskiej normalizacji.
\end{abstract}

Słowa kluczowe: zaburzenia przetwarzania słuchowego • normalizacja • standaryzacja $\bullet$ MAPA • SCAN-C • SCAN-A

\begin{abstract}
In recent years there has been a growing number of children or adults with central auditory processing disorders (CAPD) worldwide. Although CAPD is a common problem in Poland, up to date, no standardized psychometric tools for central auditory processing (CAP) have been developed. Furthermore there are no Polish normative data for tests sensitive to CAPD. The aim of the study was to present principles and methods for standardization and normalization of the CAP battery. In the first part of the paper general issues on psychometric tool construction were described. Subsequently, some information on standardization and normalization on commonly used AP test batteries (e.g. SCAN, MAPA) with satisfied psychometric properties and normative data was provided. On the basis of aforementioned tests some recommendations on the Polish tests were proposed.
\end{abstract}

Key words: central auditory processing disorders $\bullet$ normalization $\bullet$ standardization $\bullet \mathrm{MAPA} \bullet \mathrm{SCAN}-\mathrm{C} \bullet \mathrm{SCAN}-\mathrm{A}$

\section{Wprowadzenie}

Celem diagnozy ośrodkowych procesów przetwarzania słuchowego (ang. central auditory processing, CAP) jest ocena efektywności przetwarzania dźwięków na poziomie ośrodkowego układu nerwowego (OUN). Zgodnie z zaleceniami Amerykańskiego Towarzystwa Audiologicznego (AAA - American Audiology Association) podczas oceny CAP klinicysta powinien uwzględnić procesy związane z: lokalizacją dźwięków, ich różnicowaniem, analizą czasową sygnału akustycznego (rozpoznawanie wzorców akustycznych, określanie kolejności bodźców prezentowanych w krótkim odstępie czasowym, wykrywanie krótkich przerw w dźwiękach), słuchaniem obu- i rozdzielnousznym oraz rozumieniem mowy zniekształconej (filtrowanej częstotliwościowo, skompresowanej lub prezentowanej w obecności szumu) [1]. O zaburzeniach w zakresie ośrodkowych procesów przetwarzania słuchowego (ang. central auditory processing disorder, CAPD) mówi się w przypadku deficytów w zakresie przynajmniej jednego $\mathrm{z}$ ww. procesów słuchowych, przy prawidłowym słuchu obwodowym. CAPD mogą m.in. utrudniać uczenie się oparte na modalności słuchowej [2], dlatego niezbędna jest ich dokładna diagnoza, a później terapia [3].

Nadal nie wprowadzono międzynarodowych standardów oceny CAP. W związku z tym w wielu krajach opracowano specyficzne procedury diagnostyczne dla CAPD, wśród których stosuje się testy mierzące różne procesy ośrodkowe przetwarzania słuchowego. Przykładowo, w Stanach Zjednoczonych funkcjonuje kilka różnych baterii testów czułych na wykrywanie CAPD, choćby SCAN-3: C (Test for 
Auditory Processing Disorders in Children) [4] czy MAPA (Multiple Auditory Processing Assessment) [5]. Inne kraje opracowały własne zestawy testów [6] lub zaadaptowały już istniejące [7-12]. W Polsce, jak dotąd, nie stworzono baterii testów, która stanowiłaby rzetelne i trafne narzędzie do diagnostyki CAPD, mimo że podejmowano próby opracowania wybranych testów oraz norm dla nich. W praktyce oznacza to, że wyniki testów CAP mogą być interpretowane jedynie w sposób jakościowy, tzn. diagnosta może określić indywidualny profil funkcjonowania ośrodkowych procesów słuchowych bez możliwości porównania go z wynikami uzyskanymi przez osoby, u których nie rozpoznano trudności w opracowywaniu informacji akustycznej. W Instytucie Fizjologii i Patologii Słuchu w Warszawie trwają badania, których celem jest wypracowanie ogólnopolskich standardów diagnostycznych oraz normalizacja testów do badania CAP [13].

Analizując zagadnienie diagnozy z perspektywy teoretycznej, można wskazać dwa podejścia: nomotetyczne lub normatywne, czyli nastawione na wskazanie, na ile typowe lub nietypowe jest funkcjonowanie jednostki na tle grupy odniesienia; oraz idiograficzne, czyli skupione na wyjaśnieniu zjawisk jednostkowych. Podczas diagnozy psychologicznej lub pedagogicznej specjalista powinien uwzględnić dwa podejścia, lecz ze względu na cel prezentowanej pracy $\mathrm{w}$ poniższej publikacji skoncentrowano się na podejściu normatywnym. W pierwszej części przypomniano ogólne zasady standaryzacji oraz normalizacji testów, w drugiej części skupiono się na opisie istniejących na świecie wystandaryzowanych oraz posiadających normy baterii testów do badania w kierunku CAPD, a w trzeciej sformułowano zalecenia dotyczące polskiej normalizacji.

Jednym z celów diagnozy jest określenie, czy zachowanie jednostki (w tym wypadku wykonywanie zadań mierzących ośrodkowe procesy przetwarzania słuchowego) jest typowe, niższe lub wyższe dla właściwej dla badanej grupy odniesienia (na przykład populacji uczniów klas II województwa mazowieckiego). Wymaga to wcześniejszego ujednolicenia postępowania badawczego (standaryzacji) oraz normalizacji, czyli przeprowadzenia testu na reprezentatywnych dla populacji próbach, obliczeniu ich średnich oraz odchyleń standardowych.

\section{Standaryzacja}

Standaryzacja testu wiąże się $\mathrm{z}$ ujednoliceniem procedury jego przeprowadzania oraz oceniania. Jest to niezbędny zabieg pozwalający na zminimalizowanie zależności wyników od czynników związanych z 1) zachowaniem badacza oraz 2) warunkami badania [14].

W przypadku testów mierzących ośrodkowe procesy przetwarzania słuchowego niezbędne jest m.in. dokładne określenie miejsca wykonywania testu. Autorzy istniejących baterii testowych zastanawiali się, czy lepiej do tego celu nadaje się kabina audiometryczna, czy też wystarczy wyciszone pomieszczenie. Aby odpowiedzieć na to pytanie, należałoby najpierw porównać wyniki testów wykonywanych w różnych warunkach. Na przykład autorzy zrewidowanej wersji baterii SCAN-C wykazali, że warunki badania (procedura przeprowadzona w kabinie audiologicznej vs cichym pokoju) nie wpłynęły w sposób istotny statystycznie na wyniki [15]. W przypadku potwierdzenia tych wyników w populacji polskiej, w instrukcji badania można sformułować zalecenie, że badania powinny być przeprowadzone w cichym pokoju lub kabinie audiologicznej. Wskazane byłoby również podanie maksymalnej wartości szumu tła panującego w pomieszczeniu, w którym wykonywane jest badanie.

Istotne jest także ustalenie, na jakim poziomie głośności będzie prezentowany materiał bodźcowy. Przykładowo, zasady te zostały sprecyzowane $\mathrm{w}$ materiałach do baterii SCAN-C [15]. Zaleca się prezentację bodźców na stałym poziomie $50 \mathrm{~dB}$ HL w sytuacji, w której używany jest audiometr. Natomiast gdy nie stosuje się audiometru, bodźce akustyczne powinny być podawane na komfortowym dla badanego poziomie głośności. Dodatkowo należy doprecyzować kwestie związane z limitami czasowymi przeprowadzania testów, możliwością powtórzenia instrukcji w przypadku błędnego zrozumienia jej przez osobę badaną, kolejnością wykonywania testów, długością trwania sesji treningowej. Instrukcja powinna być również dostosowana do możliwości poznawczych osób badanych. Na przykład podczas standaryzacji SCANu-C autorzy uprościli instrukcję badania, dostosowując ją tym samym do dzieci w wieku wczesnoszkolnym lub przedszkolnym [15].

Podczas opracowywania standardów badania ważną kwestią jest adaptacja testów. Celem tego zabiegu jest opracowanie testu w taki sposób, aby był trafnym i rzetelnym narzędziem diagnozy w danym kraju [16]. W Polsce podczas diagnozy CAP badacze często stosują testy, które zostały opracowane w USA lub Wielkiej Brytanii. Podczas opracowywania narzędzia zdecydowano, że wpływ kontekstu kultury rodzimej na treść pozycji testowych nie zachodzi, więc adaptacja kulturowa narzędzi nie jest niezbędna. Część materiału badawczego opiera się jednak na materiale werbalnym, więc koniecznym zabiegiem była adaptacja językowa. Narzędzia stosowane do diagnozy CAP w Polsce stanowią maksymalnie wierne tłumaczenie oryginalnych pozycji testowych, co nie zawsze okazuje się właściwym rozwiązaniem. Przykładowo w Teście Słuchania Rozdzielnousznego Cyfr w języku angielskim bodźcami były wyłącznie te nazwy cyfr, które były jednosylabowe (czyli wszystkie z wyjątkiem cyfry "7”). W języku polskim mniej więcej połowa nazw cyfr jest jednosylabowa, a druga - dwusylabowa, co w przypadku wiernej adaptacji testu pod względem trudności zawęża pulę materiału do 4-5 cyfr. To z kolei zwiększa prawdopodobieństwo, że badany poprawnie „zgadnie” odpowiedź.

Konieczność dostosowania materiału testowego do potrzeb badanej populacji wykazali m.in. Dawes \& Bishop [17], porównując wyniki testów wchodzących w skład baterii SCAN-C u dzieci anglojęzycznych w wieku od 6 do 10 lat, mieszkających w Stanach Zjednoczonych i Wielkiej Brytanii. Wcześniejsze badania [18] sugerowały, że dzieci amerykańskie osiągają zdecydowanie wyższe wyniki w większości testów w porównaniu z dziećmi brytyjskimi. Dawes \& Bishop [17] wykazali, że dzieci w Wielkiej Brytanii radziły sobie gorzej niż ich rówieśnicy ze Stanów Zjednoczonych tylko w testach rozumienia mowy filtrowanej częstotliwościowo oraz mowy w szumie (znaczenie miał akcent, z jakim wypowiadano słowa). Autorzy zalecają zatem korzystanie $\mathrm{z}$ norm amerykańskich w przypadku 
populacji brytyjskiej, z tym że dopiero po uwzględnieniu poprawki na różnice narodowościowe w wyżej wymienionych testach.

\section{Normalizacja}

Kolejnym krokiem opracowania testów do diagnozy CAPD jest normalizacja, czyli opracowanie statystycznych kryteriów interpretacji wyników [16]. Bez normalizacji testów nie jest możliwe wskazanie, czy wynik uzyskany przez daną osobę jest wynikiem przeciętnym, wyższym lub niższym $\mathrm{w}$ porównaniu $\mathrm{z}$ grupą odniesienia [19]. Na tym etapie opracowywania narzędzia kluczowy jest odpowiedni dobór próby normalizacyjnej. Powinna ona być reprezentatywna dla grupy osób pod względem zmiennych, które mogą wpływać na wynik, czyli wiek, płeć, miejsce zamieszkania, wykształcenie (w przypadku badania osób dorosłych) lub wykształcenie opiekunów (w przypadku badania dzieci). Mimo że badania normalizacyjne nad testami mierzącymi CAP zostały wykonane w wielu krajach, to wyniki tych badań nie mogą być stosowane do interpretacji wyników uzyskanych przez polskich obywateli [por. 16].

Pierwszym krokiem procedury normalizacyjnej powinno być zatem wskazanie próby reprezentatywnej dla danej populacji, czyli odzwierciedlającej strukturę populacji polskiej pod względem wieku, płci, wykształcenia, miejsca zamieszkania (duże miasto, małe miasto, wieś). W przypadku tworzenia normalizacji testów dla dzieci i młodzieży warto zdecydować się na wybór tzw. warstwowy, który polega na losowaniu osób z wcześniej wydzielonych próbek (warstw) ze względu na interesujące dla badaczy/klinicystów cechy (wiek, wykształcenie rodziców, miejsce zamieszkania). Następnie należy obliczyć wyniki (średnie i odchylenia standardowe) w wyróżnionych podgrupach. W przypadku stwierdzenia, że podgrupy normalizacyjne różnią się poziomem wykonania testów mierzących CAP, należy traktować je oddzielnie, np. w przypadku wyniku wskazującego, że płeć/wykształcenie rodziców/miejsce zamieszkania różnicuje podgrupy normalizacyjne, interpretując wynik jednostki, należy go porównać z właściwą dla niej grupą. Badania normalizacyjne testów poznawczych wykazują, że wykształcenie rodziców jest częstym czynnikiem różnicującym poziom wykonania zadań przez dzieci, więc należy to uwzględnić podczas procedury normalizacyjnej [16].

Próba normalizacyjna powinna być na tyle duża, aby wyniki uzyskane na innej grupie dobranej pod względem interesujących nas zmiennych były zbliżone [14]. W praktyce oznacza to badanie kilkudziesięciu osób w każdej podgrupie. Oczywiście im więcej osób zbadamy, tym bardziej stabilne będą uzyskane wartości. Przykładowo w SCAN-C zbadano ok. 50 osób w danej grupie wiekowej [4]. Wielkość prób powinna być proporcjonalna do liczby osób w danej grupie (np. wiekowej, narodowościowej) w całej populacji.

Kolejnym krokiem jest ustalenie rzetelności testu. Zaleca się, by wynosiła ona min. 0,8 [14]. Do najczęściej stosowanych metod szacowania rzetelności testu należą: metoda test-retest, metoda połówkowa, metoda wersji równoległych, ocena zgodności wewnętrznej oraz sędziów kompetentnych. W przypadku testów mierzących CAP powtarzalność wyników może być sprawdzona z wykorzystaniem metody test-retest lub wersji połówkowych. Należy pamiętać, że w przypadku badania dzieci, ze względu na szybkie zmiany rozwojowe, powtórne badanie powinno być wykonane w ciągu paru tygodni [20]. Jeśli powtórne badanie nie jest możliwe, stosuje się metodę połówkową polegającą na porównaniu wyników uzyskanych w pozycjach testowych równoważnych pod względem trudności.

Istotnym czynnikiem, który powinien być uwzględniony podczas tworzenia narzędzia psychometrycznego, jest trafność testu [20]. Termin ten mówi, na ile operacjonalizacja danej cechy psychologicznej jest prawidłowa, tzn. czy badacz posługujący się danym testem jest w stanie osiągnąć cel badawczy, np. diagnozę procesów związanych $\mathrm{z}$ uwagą słuchową, a nie np. ogólnym poziomem funkcjonowania poznawczego. Wyróżnia się trafność teoretyczną, kryterialną oraz prognostyczną. O wysokiej trafności teoretycznej możemy mówić, gdy zostaną spełnione następujące warunki:

1) grupy wyodrębnione na podstawie kryterium zewnętrznego (które zgodnie $\mathrm{z}$ teorią powinno je różnicować) faktycznie będą osiągały istotnie różne wyniki w interesującym nas teście,

2) w przypadku testów/skal wielowymiarowych osiąga się wysoką korelację między podskalami lub pozycjami mierzącymi daną cechę psychologiczną.

Trafność kryterialną szacuje się poprzez obliczenia korelacji między wynikami $\mathrm{w}$ interesującym nas teście a innym rzetelnym i trafnym narzędziem psychometrycznym mierzącym ten sam wymiar psychologiczny [20]. W przypadku testów mierzącym CAP obliczanie trafności kryterialnej będzie trudne, ponieważ w Polsce nie ma innych wystandaryzowanych narzędzi mierzących ośrodkowe procesy słuchowe. Na etapie tworzenia baterii testów (np. SCAN-A) sprawdzano, czy obniżone wyniki w testach uzyskują osoby, u których rozpoznano CAPD na podstawie innych metod, np. wywiadu medycznego oraz wykonania testów uwagi słuchowej i funkcji językowych.

Ocenienie trafności prognostycznej polega na porównaniu wyników osiąganych w danym teście z rzeczywistymi osiągnięciami, np. szkolnymi, lub ryzykiem wystąpienia innych zaburzeń [20]. W przypadku stwierdzenia CAPD konieczne jest ustalenie, czy obniżony poziom wykonania $\mathrm{w}$ teście u danego dziecka współwystępuje $\mathrm{z}$ innymi zaburzeniami wieku rozwojowego, takimi jak dysleksja czy nadpobudliwość psychoruchowa.

\section{Przykładowe baterie testów do oceny ośrodkowych procesów przetwarzania słuchowego}

\section{SCAN-3: C Test for Auditory Processing Disorders in Children - Revised [4]}

Bateria testów mierzących ośrodkowe procesy przetwarzania słuchowego u dzieci w wieku od 5 do 12 lat. Obejmuje 3 testy przesiewowe przeznaczone do oceny ryzyka występowania CAPD, 4 testy diagnostyczne i 3 dodatkowe. Testy sprawdzają zdolność wykrywania krótkich przerw w bodźcach słuchowych, percepcji mowy zniekształconej (filtrowanej częstotliwościowo i skompresowanej) 
lub w obecności sygnału zakłócającego oraz słuchania rozdzielnousznego $\mathrm{w}$ warunkach uwagi rozproszonej i ukierunkowanej.

W raporcie technicznym na temat baterii [4] przedstawiono warunki, w jakich należy wykonywać badania (w przypadku, gdy stosuje się audiometr, poziom głośności ma być stały - $50 \mathrm{~dB} \mathrm{HL}$, w pozostałych warunkach materiał bodźcowy należy prezentować na komfortowym dla słuchacza poziomie głośności).

Proces standaryzacji baterii SCAN-3: C trwał od września 2007 r. do lipca 2008 r. Badaniami objęto 525 dzieci w wieku 5: 0 do 12: 11. Testy przeprowadziło 105 lekarzy audiologów oraz licencjonowanych specjalistów z zakresu mowy i języka. Grupę normatywną stanowiły dzieci mieszkające w Stanach Zjednoczonych, których ojczystym językiem był angielski. Próba standaryzacyjna została podzielona na grupy jednorodne pod względem rasy/narodowości, regionu zamieszkania i poziomu edukacji opiekuna dziecka. Rzetelność testów szacowano na podstawie techniki test-retest i oceny spójności wewnętrznej. Sprawdzono również zgodność wyników uzyskanych przez różnych eksperymentatorów. Współczynniki rzetelności, szacowane techniką test-retest, wynosiły od 0,54 do 0,73 dla poszczególnych testów i 0,77 dla wszystkich testów w baterii łącznie (testy zgrupowano w jeden czynnik nazwany auditory processing composite, APC). Średni współczynnik rzetelności obliczony dla APC wynosił aż 0,91. Współczynniki zgodności wyników uzyskanych przez różnych badaczy dla poszczególnych testów również był wysokie i zawierały się w granicach od 0,98 do 0,99. Błędy standardowe pomiaru (ang. standard error of measurement, SEM) obliczono oddzielnie dla poszczególnych testów z baterii oraz dla APC w poszczególnych grupach wiekowych.

Trafność szacowano na podstawie zawartości treściowej testów, sposobu udzielania odpowiedzi przez uczestników badania, korelacji między poszczególnymi testami oraz na podstawie wyników uzyskanych u dzieci z CAPD. SCAN-3: C mierzy różne procesy słuchowe (np. rozumienie mowy zniekształconej czy czasowe aspekty opracowywania informacji słuchowej), które zostały wymienione w raporcie technicznym ASHA z 2005 r. Podczas przeprowadzania badań notowano sposób udzielania odpowiedzi. Do próby normatywnej włączono wyniki tylko tych dzieci, które właściwie zrozumiały instrukcje do testów. Najwyższe współczynniki korelacji wykazano między testami słuchania rozdzielnousznego $\mathrm{w}$ warunkach uwagi rozproszonej i ukierunkowanej $(0,71)$. Wykazano również istotne różnice $\mathrm{w}$ wykonaniu testów między dziećmi w wieku 5: 0-12: $11(\mathrm{n}=40)$, u których rozpoznano ośrodkowe zaburzenia przetwarzania słuchowego, a grupą kontrolną (bez CAPD) składającą się z osób dobranych pod względem wieku, rasy/narodowości oraz poziomu wykształcenia opiekuna. Średnie lub wysokie wartości współczynnika wielkości efektu, zarówno dla pojedynczych testów, jak i dla APC, wskazują, że bateria SCAN-3: C jest narzędziem czułym na wykrywanie zaburzeń ośrodkowych procesów przetwarzania słuchowego.

Czułość diagnostyczną i użyteczność baterii w klinice szacowano, oceniając czułość i specyficzność testów. Czułość i specyficzność testów przesiewowych wynosiła od 0,25 do 0,88 , a testów przesiewowych i diagnostycznych łącznie: od 0,2 do 0,9 .

\section{SCAN-A: A test for Auditory Processing Disorders in Adolescents and Adults [22]}

Bateria testów przeznaczona do badania ośrodkowych procesów przetwarzania słuchowego u młodzieży i osób dorosłych. Zawiera 4 podtesty mierzące 1) percepcję słów filtrowanych częstotliwościowo, 2) rozumienie mowy w obecności sygnału zakłócającego, 3) słuchanie rozdzielnouszne słów jednosylabowych i 4) słuchanie rozdzielnouszne zdań.

Badania standaryzacyjne przeprowadziło 50 lekarzy audiologów w klinikach uniwersyteckich, w prywatnych gabinetach i szpitalach wojskowych, w których było możliwe wykonanie audiometrii tonalnej dla częstotliwości: 500, 1000, 2000 i $4000 \mathrm{~Hz}$. Osoby, których progi słyszenia były wyższe niż $20 \mathrm{~dB}$ HL, jak również osoby, u których różnica $\mathrm{w}$ poziomie słyszenia między uszami wynosiła $10 \mathrm{~dB}$ lub więcej dla minimum jednej $\mathrm{z}$ badanych częstotliwości, zostały wykluczone $\mathrm{z}$ badania.

W badaniach standaryzacyjnych uczestniczyło 125 osób w wieku od 12 do 50 lat, obu płci, z 21 miejscowości w 4 głównych regionach Stanów Zjednoczonych. Próbę stanowili głównie biali Amerykanie (ok. 77\% badanej populacji), Afroamerykanie i Hiszpanie, dla których pierwszym językiem był angielski.

Testy wchodzące w skład baterii są rzetelne i trafne. Współczynnik alfa Cronbacha (współczynnik rzetelności) jest wysoki i wynosi 0,77 . Trzydzieści osiem osób dorosłych dwukrotnie wykonało testy w odstępie 5 miesięcy. Współczynnik rzetelności mierzony techniką test-retest dla całej baterii wynosił 0,69, a SEM - 2,8. Testy dobrze różnicują osoby z CAPD i osoby bez ośrodkowych zaburzeń przetwarzania słuchowego. Wniosek ten sformułowano na podstawie analizy dyskryminacyjnej. Testy z baterii wykonało dwadzieścia pięć osób z CAPD między 12 a 18 r.ż. i grupa 25 osób bez zaburzeń ośrodkowych procesów słuchowych, nieróżniąca się od klinicznej pod względem wieku, płci i rasy. CAPD rozpoznano na podstawie wyników testów językowych, audiologicznych oraz wywiadu medycznego. W celu określenia, czy SCAN-A poprawnie różnicuje CAPD, w analizie dyskryminacyjnej zastosowano model detekcji sygnału. Na podstawie wykonania testów w $86 \%$ przypadków można było poprawnie odróżnić CAPD od normy.

Analiza związku między poszczególnymi testami w SCAN-A wykazała umiarkowaną korelację między testami słuchania rozdzielnousznego słów i zdań. Natomiast współczynniki korelacji testu rozumienia mowy w obecności sygnału zakłócającego $\mathrm{z}$ innymi testami w baterii były niskie, co wskazuje, że mierzy on inny proces niż pozostałe próby.

\section{MAPA (Multiple Auditory Processing Assessment) [5,22]}

Zestaw testów do oceny ośrodkowych procesów przetwarzania słuchowego u dzieci od 8 r.ż. i osób dorosłych 
w Wielkiej Brytanii. Niektóre testy tworzące amerykańską baterię SCAN zawierają materiał werbalny, dlatego możliwości ich stosowania w populacji brytyjskiej były ograniczone. W związku z tym opracowano baterię MAPA składającą się z 5 podstawowych testów (Jednouszny Test Słuchowej Uwagi Selektywnej, Test Tappingu, Test Rozpoznawania Wzorców Częstotliwości, Test Słuchania Rozdzielnousznego Cyfr i Test Słuchania Rozdzielnousznego Zdań) oraz testów dodatkowych takich jak Test Rozpoznawania Wzorców Długości, Test Rozumienia Mowy w Szumie i Test Wykrywania Przerw. W celu sprawdzenia związków między ww. testami w kilku badaniach wykonano analizę czynnikową. Odrębne czynniki tworzyły: Jednouszny Test Słuchowej Uwagi Selektywnej i Test Rozumienia Mowy w Szumie, a także Testy Słuchania Rozdzielnousznego Cyfr i Zdań oraz Testy Rozpoznawania Wzorców Częstotliwości i Test Tappingu.

Czułość testów tworzących baterię MAPA wahała się od 25\% dla Testu Słuchania Rozdzielnousznego Zdań do 40\% dla Jednousznego Testu Słuchowej Uwagi Selektywnej. Czułość szacowana dla 3 testów łącznie (Jednouszny Test Słuchowej Uwagi Selektywnej, Test Słuchania Rozdzielnousznego Cyfr i Test Rozpoznawania Wzorców Częstotliwości) wyniosła 90\%. Specyficzność obliczona dla dowolnych konfiguracji 4 ww. testów wynosiła 100\%. Czułość i specyficzność testów była szacowana na podstawie kryterium wykonania poniżej 2 odchyleń standardowych poniżej średniej przynajmniej w jednym $\mathrm{z}$ testów. Summers i wsp. (2003) oceniali rzetelność testów wchodzących w skład MAPY, wykorzystując technikę test-retest. Badania zostały wykonane u 19 dzieci w wieku od 8 do 11 lat. Współczynniki rzetelności dla wszystkich testów były wysokie, większe niż 0,7. MAPA jest dostępna w dwóch alternatywnych, równorzędnych wersjach.

\section{Podsumowanie}

Na podstawie powyższych informacji można zaproponować następujący plan prac zmierzających do opracowania baterii testów czułych na wykrywanie ośrodkowych procesów przetwarzania słuchowego:

1. Określenie ośrodkowych procesów słuchowych, które będą badane (np. zgodnie z aktualnie obowiązującymi wytycznymi Amerykańskiego Towarzystwa Audiologicznego [1]).

2. Wybór testów mierzących ośrodkowe procesy przetwarzania słuchowego (opracowanie nowego zestawu testów na podstawie testów, które zostały opracowane w innych krajach, lub adaptacja językowa istniejących baterii) oraz opracowanie materiału bodźcowego (nagranie, poziom głośności).

3. Charakterystyka badanej populacji (wiek, płeć, poziom wykształcenia, miejsce zamieszkania) i wybór próby reprezentatywnej dla populacji.

4. Ujednolicenie warunków przeprowadzania poszczególnych testów (miejsce badania, instrukcje do testów, kolejność ich wykonania i przeszkolenie badaczy, tak aby badanie przebiegało zawsze w identyczny sposób).

5. Psychometryczna ocena trafności i rzetelności testów.

Publikacja powstała $w$ zwiazku $z$ realizacja projektu pn. „Zintegrowany system narzędzi do diagnostyki i telerehabilitacji schorzeń narządów zmysłów (słuchu, wzroku, mowy, równowagi, smaku, powonienia)" INNOSENSE, wspólfinansowanego przez Narodowe Centrum Badań i Rozwoju w ramach Programu STRATEGMED.

\section{Piśmiennictwo:}

1. American Academy of Audiology (AAA). Diagnosis, Treatment and Management of Children and Adults with Central Auditory Processing Disorder. 2010. http://www.citeulike.org/ group/12655/article/9445717.

2. Senderski A. Rozpoznawanie i postępowanie w zaburzeniach przetwarzania słuchowego u dzieci. Otorynolaryngologia, 2014; 13(2): 77-81.

3. Skoczylas A, Lewandowska M, Pluta A, Kurkowski Z, Skarżyński H. Ośrodkowe zaburzenia słuchu - wskazówki diagnostyczne i propozycje terapii. Nowa Audiofonol; 2012; 1(1): 11-18.

4. Keith RW. SCAN-3: C Test for Auditory Processing Disorders in Children - Revised. Technical report; 2007.

5. Schow RL, Seikel JA, Brockett JE, Whitaker MM. Multiple Auditory Processing Assessment, MAPA. Test manual. Auditec, Idaho State University; 2007.

6. Golding M, Birtles $\mathrm{G}$, red. Macquarie University speech tests. Sydney: Macquarie University; 2001.

7. Campbell NG, Wilson WJ. The performance of South African English first language child speakers on a "low linguistically loaded" central auditory processing test protocol. South Afr J Commun Disord Suid-Afr Tydskr Vir Kommun, 2003; 50, 15-18.

8. Dawes P, Bishop DVM. The SCAN-C in testing for auditory processing disorder in a sample of British children. Int $\mathrm{J} \mathrm{Au}$ diol, 2007; 46: 780-86.
9. Demanez L, Dony-Closon B, Lhonneux-Ledoux E, Demanez JP. Central auditory processing assessment: a French-speaking battery. Acta Otorhinolaryngol Belg, 2003; 57: 275-90.

10. Fuente A, McPherson B. Auditory processing tests for Spanish-speaking adults: an initial study. Int J Audiol, 2006; 45: 645-59.

11. Kelly A. Normative data for behavioural tests of auditory processing for New Zealand school children aged 7 to 12 years. Aust NZ Audiol, 2007; 29: 60-64.

12. Wohlleben B, Rosenfeld J, Gross M. Auditive Verarbeitungs und Wahrnehmungsstörungen (AVWS): Erste Normwerte zur standardisierten Diagnostik bei Schulkindern. HNO, 2007; 55: 403-10.

13. Skarżyński PH, Włodarczyk A, Kochanek K, Piłka A, Jędrzejczak WW, Olszewski $€$ i wsp. Central auditory processing disorder (CAPD) tests in a school-age hearing screening programme - analysis of 76,429 children. Ann Agric Environ Med, 2015; 22(1): 90-95.

14. Keith RW. SCAN C: Test for auditory processing disorders in children. San Antonio: Psychological Corporation; 2000.

15. Brzeziński J. Metodologia badań psychologicznych. Wydawnictwo PWN; 2003.

16. Hornowska E. Testy psychologiczne. Teoria i praktyka. Wydawnictwo Scholar; 2010. 
17. Dawes P, Bishop DVM. The SCAN-C in testing for auditory processing disorder in a sample of British children. Int J Audiol, 2007; 46: 780-86.

18. Marriage J, King J, Briggs J, Lutman ME. The reliability of the SCAN test: results from a primary school population in the UK. Br J Audiol, 2001; 35(3): 199-208.

19. Rynkiewicz A. Normy i normalizacja. W: Fronczyk K, red. Psychometria, podstawowe zagadnienia. Warszawa: Wyższa Szkoła Finansów i Zarządzania w Warszawie; 2009, 205-29.
20. Krasowicz-Kupis G, Wiejak K, Gruszyńska K. Katalog metod diagnozy rozwoju poznawczego dziecka na etapie edukacji przedszkolnej i wczesnoszkolnej. Warszawa: Instytut Badań Edukacyjnych; 2015.

21. Keith RW. SCAN-A. A test for auditory processing disorders in adolescents and adults. A technical report. Pearson Education; 2008.

22. Domitz DM, Schow RL. A new CAPD battery - multiple auditory processing assessment: factor analysis and comparisons with SCAN. Am J Audiol, 2000; 9: 101-11. 